\title{
Oscillating among Different Traditions of Grounded Theory
}

\author{
${ }^{1}$ Innocent Sigauke, PhD, ${ }^{2}$ Kenneth Swansi, PhD and ${ }^{3}$ Peter Tsvara, PhD \\ ${ }^{1}$ Assistant Professor of Marketing, Solusi University, Zimbabwe \\ ${ }^{2}$ Associate Professor of Economics and Strategic Management, AllAS, Philippines \\ ${ }^{3}$ Professor of Educational Management, Solusi University, Zimbabwe \\ *Corresponding author: sigaukei@solusi.ac.zw
}

\begin{abstract}
Grounded theory is one of the major research designs used in qualitative studies. However, there is more than one genre of grounded theory. Some authors highlight the basic dichotomy between Strauss and Glaser's approaches to grounded theory while still others go further to highlight that the grounded theory method is in fact more than a dichotomy, but a 'contested concept.' Though others seem to downplay such a contest, there are others who suggest that one does not have to choose between the two approaches, adding that a balanced approach is ideal as there is a lot to learn from all grounded theory forbearers. This paper provides an outline of the uncontested concepts of grounded theory while highlighting the options among the various grounded theory approaches.
\end{abstract}

Key words: Grounded theory, qualitative research, coding, data analysis, approach, traditions

\section{Introduction}

Grounded theory is a rigorous systematic inductive method for theory generation (Glaser 1998). In contrast to the logico-deductive approach, the grounded theory method derives theory from data (Goulding, 1998). As a result, the resultant theory is not only data driven but empirically informed so its verification is done during the execution of the research rather than through follow up quantitative data (Glaser \& Strauss, 1967; Goulding, 1998).

There are several genres or approaches of grounded theory. Kenny and Fourie (2015) mention three as follows: (a) the classic or Glaserian strand, (b) the Straussian strand and (c) the more recent constructivist strand which is espoused by Charmaz (2006) as cited Birks and Mills (2011). According to Goulding (1998), the genres differ in their styles and terminology. The Glaserian approach, for instance, emphasizes emergence of the theory while the Straussian approach stresses creation of the theory. On the other hand, the approach outlined by Charmaz suggests that the theory can be constructed. The outline by Kenny and Fourie (2015) also highlights that the three approaches differ in their philosophical underpinnings as well as the way they handle literature and their approaches to coding. However the theories seem to agree on a number of key issues such as the constant comparative technique, memoing and theoretical sampling.

It is not easy for a novice grounded theorist to choose among the different techniques and philosophical approaches espoused in the three genres of grounded theory. In fact, novice grounded theorists may end up confused due to various reasons. First, there is uncertainty on the criteria for selection among the various tools and techniques of different genres of grounded theory. Secondly, the diffusion of the grounded theory among various disciplines from sociology to public health has meant that the method has inevitably evolved to incorporate the intricate issues from different disciplines. Thirdly, the increasing penchant for multimethod designs which involves combining grounded theory with other designs has added new dimensions for consideration. Fourthly, there seem

72 East African Journal of Education and Social Sciences (EAJESS) 1(1)72-78 
to be pluralistic approaches within each grounded theory genre. Finally, calling for grounded theory purism from authors like Glaser (1998) on one hand, and calling for its remodeling by others like Bryant (2010), on the other hand, makes it even more confusing.

This paper suggests that a novice grounded theorist may oscillate among the three genres. Even though attempts to bring structure to qualitative studies may be generally frowned upon (Goulding, 1998), we suggest that a framework that provides loose guidelines on how to navigate the genres of grounded theory is especially useful to novice grounded theorists. Hence, we outline options and rules of thumbs that may be useful in navigation among the three genres. Such an outline is necessary because it presents some heuristics on how to navigate among the different genres thereby potentially reducing the confusion.

\section{Overview of Grounded Theory Method}

Glaser (1998) describes grounded theory as an inductive method that is designed to result in the systematic generation of theory. The method provides rules at every stage, hence the omission of any of the rules diminishes the quality of the theory produced. Glaser, (1998) as well as Glaser and Holton (2004) contend that while the method uses qualitative data, it should not be confused with a qualitative method. Correspondingly, Glaser and Holton (2004) raise a red flag over Creswell 's classification of the grounded theory method as one of the big five methods of qualitative research. They suggest that the grounded theory is not a qualitative research methodology but an independent method.

Our view is that grounded theory is a fully-fledged method with at least three distinct genres. The view is informed by several observations. First, the setting and assumptions that informed the birth of the grounded theory method have changed. For example, Goulding (1998) highlights that the method was developed as a protest against empirically uninformed theory on one end and extreme empiricism on the other hand. Those circumstances no longer exist. The method has matured with its own pool of tools and techniques. These tools and techniques have evolved over the years and have been used effectively to develop theory. Bryant (2003) also mentioned that Glaser's and Strauss' early conceptual and philosophical foundations are no longer tenable.
Second the grounded theory method has diffused from the discipline of sociology to fields as diverse as psychology and marketing to public health. As a result, the different researchers in diverse areas have brought varied perspectives to the grounded theory method (Tan 2010). The implication is that the grounded theory method has evolved into a fully-fledged method. While it is important to maintain necessary quality controls on the method, we suggest that such measures should not stifle the purpose of the method which is to develop a theory that is not only empirical but also informed by data.

Finally, the clear differences among the three approaches to grounded theory present novice researchers with the arduous task of selecting tools and techniques that they can use. Tan (2010) highlights that the discussions on the different grounded theory approaches only serves to confuse grounded theorists. What novice researchers require are as clear guidelines as possible. Hence the oscillating framework suggested in this study is set to mitigate the confusion.

\section{Grounded Theory Challenges and Pitfalls}

Notwithstanding the call to treat grounded theory as an established methodology, there are a number of challenges that have been highlighted about the use of the grounded theory method. Goulding (1998) highlights three potential challenges about the grounded theory method. First is what she terms generation erosion. The erosion arises because of misinterpreting the grounded theory method. While the sample size is predetermined and fixed, for most researches a sample in a grounded theory study is emergent depending on the saturation of the theory under consideration. The invention of such inflexible rules like the imposition of sample size requirements for a grounded theory study or other inaccurate translations of the method contribute to the erosion. Premature closure is the second challenge. It is a result of concluding a grounded theory study too early or the inadequate analysis of data. If a researcher focuses on a particular sample size for instance, he/she may conclude the research before theoretical saturation. Finally, she highlights methodological iniquities such as the abuse of the method and its philosophy as well as mixing up the method, for example presenting a study that has 
used another method as a grounded theory study, the use of quantitative descriptors and so on.

These pitfalls should be considered in a paper like this one because its suggestions have methodological implications. The suggestions presented in this paper are not expected to dilute the grounded theory method. Instead, they should make it easier to use the grounded theory method. For that reason, it is important to observe that the suggestions presented in this paper are not prescriptive. Having considered potential pitfalls, the subsequent section presents the cannons of the grounded theory method.

\section{Pillars of the Grounded Theory Method}

In any grounded theory study, readers may be curious to learn the genre of grounded theory that was used. While Fukofuka (2012) highlights the dichotomy between Strauss's and Glaser's approaches to grounded theory, still others like Brayant et al. (2010) go further to highlight that the grounded theory method is in fact more than a dichotomy, but a 'contested concept'. However, others like Charmaz (2014) and Corbin and Strauss (2015) seem to downplay such a contest. In fact, Birks and Mills (2011) suggest that one does not have to choose between the two approaches, adding that a balanced approach is ideal as there is a lot to learn from all grounded theory forbearers.
They suggest the essence of grounded theory methods to be "initial coding and categorization of data; concurrent data generation or collection and analysis; writing memos; theoretical sampling; constant comparative analysis using inductive and abductive logic; theoretical sensitivity; intermediate coding; selecting a core category; theoretical saturation; and theoretical integration" (p. 9).

Charmaz (2014, p. 15) presents a similar outline contending that grounded theorists:

1. Conduct data collection and analysis simultaneously in an iterative process

2. Analyze actions and processes rather than themes and structures

3. Use comparative methods

4. Draw on data (e.g. narratives and descriptions) in service of developing new conceptual categories

5. Develop inductive abstract analytic categories through systematic data analysis

6. Emphasize theory construction rather than description or application of current theories

7. Engage in theoretical sampling

8. Search for variation in the studied categories or process; and

9. Pursue developing a category rather than covering a specific empirical topic.

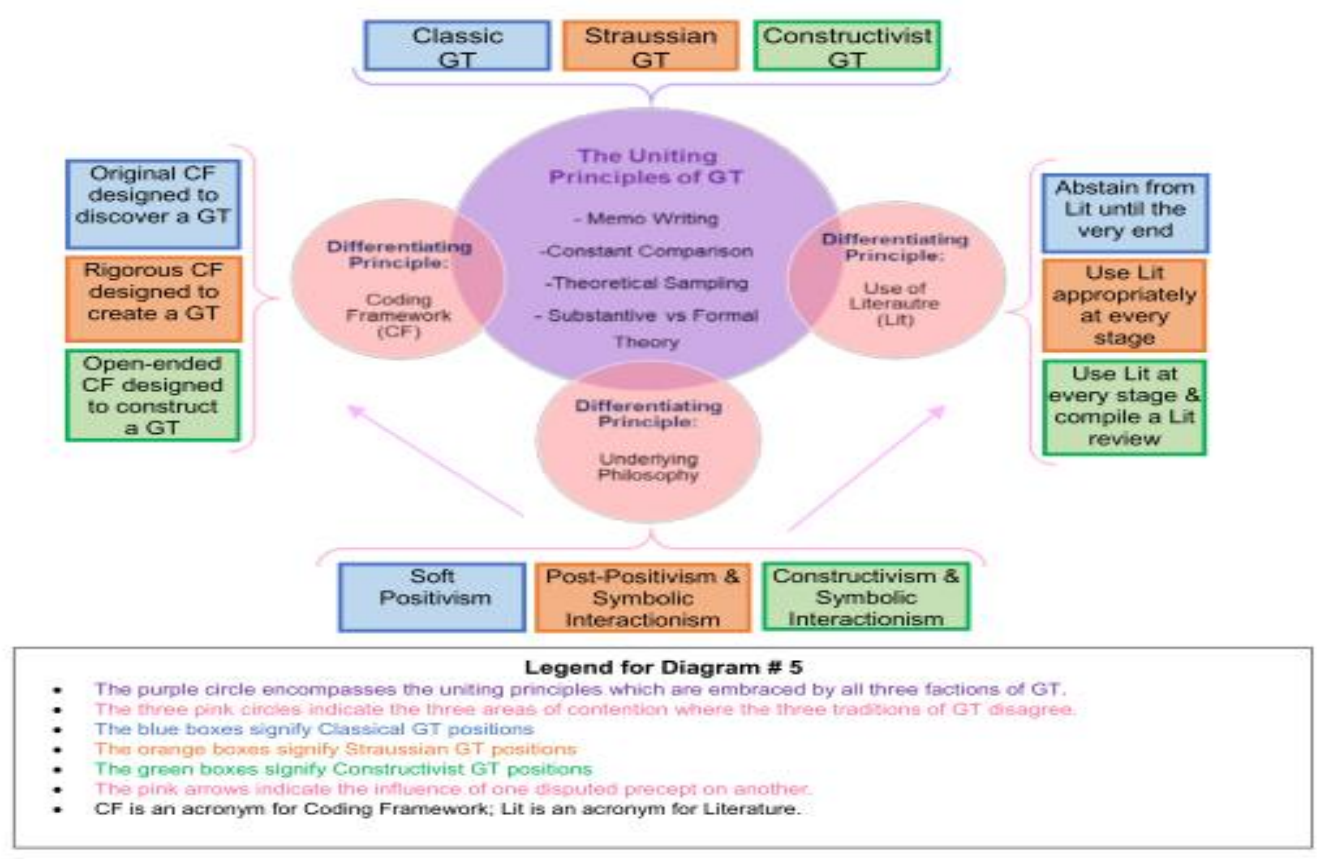

Figure 1: The Uniting and Differentiating Principles of Ground Theory 
Corbin and Strauss (2015) also concurred but were less prescriptive noting that the grounded theory method is distinct in that, first, the theory that emerges is derived from the data collected and is not preconceived before data collection and second, data collection and analysis are not only related and simultaneous but also guide in ensuing data collection, hence data collection and analysis are ongoing for the duration of the research. It seems that there is some consensus on a family of grounded theory methods. We therefore suggest that these uncontested issues in grounded theory constitute the pillars of the grounded theory method.

\section{Oscillating among Different Traditions of Grounded Theory}

While there are some issues that are not contested in grounded theory, there are others which are. Kenny and Fourie (2015, p. 1286) present an apt evaluation of the three main schools of thought highlighting the agreed and contested areas among them. This is reflected in Figure 1 which illustrates the similarities and differences among the grounded theory approaches.

While Table 1 presents the options of the different coding options and cycles in grounded theory studies and the corresponding genre (Birks and Mills, 2011, p. 116), Table 2 presents some heuristics on how to navigate among the different genres of grounded theory.

Heuristics for Oscillating among the different genres of grounded theory:

1. Philosophical orientation. Choose one philosophy that best approximates your worldview. The choice of philosophical orientation determines the approach that can be taken towards the use of literature, choice of coding framework and the nature of the theory that characterizes the data.

2. Use of literature.

a. It is possible to begin a study without using literature at the beginning of the research and later shift to using literature throughout the study.

b. However, it would be difficult to start using literature then change to a classic approach where the use of literature is discouraged.
3. Coding frameworks.

a. Any combination of the classic grounded theory coding options and cycles illustrated in Table 1 can be selected when the Glaserian approach has been selected.

b. When the Strusasian route has been chosen, the coding outlined by Corbin and Strauss (1990; 1998) can be used (cited in Birks \& Mills 2011).

c. When the option by Charmaz has been selected, then the coding options by Charmaz 2006 in Table 1 can be employed (cited in Birks \& Mills 2011).

d. The coding options in Table 1 illustrate several points: First, the coding techniques in the first cycle of coding revolve around open or initial coding. The techniques for the three genres are largely similar at this first cycle. Second, the techniques selected at the second and third cycles are different among the genres and within each genre. Third, techniques from among the different genres have been selected. So, it may be possible to select the most effective combination from any of the genres.

4. Resultant theory.

a. The philosophical orientation that characterizes the study determines whether the theory is emergent, created, or constructed.

b. While the Glaserian philosophical approach seems distinct, it seems there are overlaps between the other two.

c. The resultant theory will thus be emergent if the overriding philosophical orientation is soft positivist.

d. Similarly, the theory will be created if the orientation is post positivism.

e. The theory will be constructed if the orientation is constructivist.

f. Finally, the oscillation that may occur among choice of techniques selected among the different genres, for example on the use of literature, or the coding techniques chosen from among the different genres, will not necessarily affect the major philosophical orientation guiding the research.

g. Consequently, the resultant theory will either be emergent, created or constructed depending on the overriding philosophy chosen. 
Table 1: Coding Options and Cycles

\begin{tabular}{|c|c|c|c|c|c|c|}
\hline Source & Proponent (s) & Initial Coding & $\begin{array}{l}\text { Intermediate } \\
\text { Coding }\end{array}$ & \multicolumn{2}{|c|}{ Advanced Coding } & Theory \\
\hline $\begin{array}{l}\text { (Birks } \\
\& \text { Mills, } \\
\text { 2011) }\end{array}$ & $\begin{array}{l}\text { Glasser \& } \\
\text { Strauss (1967) }\end{array}$ & $\begin{array}{l}\text { Coding \& } \\
\text { comparing } \\
\text { incidents }\end{array}$ & $\begin{array}{l}\text { Integrating } \\
\text { categories and } \\
\text { properties }\end{array}$ & \multicolumn{2}{|c|}{ Delimiting the theory } & $\begin{array}{l}\text { Emerges } \\
\text { (Classic) }\end{array}$ \\
\hline $\begin{array}{l}\text { (Birks } \\
\text { \& Mills, } \\
\text { 2011) }\end{array}$ & Glasser (1978) & Open coding & Selective coding & \multicolumn{2}{|c|}{ Theoretical coding } & $\begin{array}{l}\text { Emerges } \\
\text { (Classic) }\end{array}$ \\
\hline (Böhm, 2004) & Böhm, (2004) & Open & Axial & \multicolumn{2}{|l|}{ Selective } & $\begin{array}{l}\text { Emerges } \\
\text { (Classic) }\end{array}$ \\
\hline $\begin{array}{l}\text { (Saldaña, } \\
\text { 2016) }\end{array}$ & Saldana (2016) & $\begin{array}{l}\text { Initial, process, } \\
\text { invivo }\end{array}$ & Focused, axial, & \multicolumn{2}{|c|}{ Theoretical } & $\begin{array}{l}\text { Emerges } \\
\text { (Classic) }\end{array}$ \\
\hline $\begin{array}{l}\text { (Kenny \& } \\
\text { Fourie, } \\
(2015)\end{array}$ & $\begin{array}{l}\text { Holton }(2010 \\
\text { 2017) }\end{array}$ & \multicolumn{2}{|c|}{$\begin{array}{l}\text { Substantive coding (open coding; } \\
\text { selective) }\end{array}$} & \multicolumn{2}{|c|}{ Theoretical coding } & $\begin{array}{l}\text { Emerges } \\
\text { (Classic) }\end{array}$ \\
\hline (Birks & $\begin{array}{l}\text { Strauss \& Corbin } \\
\text { 1990; 1998) }\end{array}$ & Open coding & Axial coding & \multicolumn{2}{|c|}{ Selective coding } & $\begin{array}{l}\text { Created } \\
\text { (Straussian) }\end{array}$ \\
\hline $\begin{array}{l}\text { (Kenny \& } \\
\text { Fourie, 2015) }\end{array}$ & $\begin{array}{l}\text { Strauss \& Corbin } \\
\text { (1990) }\end{array}$ & Open coding & Axial coding & \multirow[t]{2}{*}{$\begin{array}{l}\text { Selective } \\
\text { coding }\end{array}$} & $\begin{array}{l}\text { Conditional } \\
\text { matrix }\end{array}$ & $\begin{array}{l}\text { Created } \\
\text { (Straussian) }\end{array}$ \\
\hline & Charmaz & Initial or open & Refocused & & & $\begin{array}{l}\text { Constructed } \\
\text { (Constructivist) }\end{array}$ \\
\hline $\begin{array}{l}\text { (Birks } \\
\text { \& Mills, } \\
\text { 2011) }\end{array}$ & Charmaz (2006) & Initial coding & Focused coding & \multicolumn{2}{|c|}{ Theoretical coding } & $\begin{array}{l}\text { Constructed } \\
\text { (Constructivist) }\end{array}$ \\
\hline
\end{tabular}

\section{Discussion}

Several points can be highlighted form the ensuing outline. As a starting point, we have suggested that the multiple genres of grounded theory are confusing for novice grounded theorists. The multiple available frameworks, the diffusion of the discipline, the different positions taken by scholars as well as the founders of the methodology and the growing tendency to mix grounded theory with other methods all add to the confusion. At the same time, we suggest that the grounded theory method is a fully-fledged method.

While it would seem that the points of confusion presented suggest a call to remodel the grounded theory method, part of the remodeling involves accepting the three genres of grounded theory as complete and acceptable approaches to the grounded theory method. Following up on that, we propose that a guideline on how to navigate the different genres is appropriate. As a result, we have suggested that the philosophical orientation that a researcher chooses will determine how he or she will oscillate among the different genres of grounded theory.
Oscillation represents a pragmatic philosophical orientation. It suggests that the different genres of grounded theory do not have value in and of themselves. Rather, if the pillars of the methodology are adhered to, then the choice for specific techniques or approach to be adopted regarding literature and coding will depend on the scientific methods and utility that goes with the choice.

\section{Conclusions}

In conclusion, an oscillation outline goes a long way in addressing some of the questions that grounded theory researchers may encounter. The idea of oscillating is founded on the idea that there are grounded theory pillars such as constant comparison, theoretical sampling, memoing and substantive or formal theory. These cannons represent the areas where there is consensus among the different approaches to grounded theory. Aside of these cannons, a researcher can make choices on the other aspects such as the use of literature and coding. The choices are shaped by the philosophical orientation adopted. Hence a researcher can choose between (a) selecting one genre and its suggested tools as illustrated in Table 2 and figure 1 or oscillating among the different traditions. 
Table 2: Oscillating among the Different Grounded Theory Genres

\begin{tabular}{|c|c|c|c|c|}
\hline \multirow[t]{2}{*}{ Variable } & \multicolumn{3}{|l|}{ Genre of grounded theory } & \multirow{2}{*}{$\begin{array}{l}\text { Oscillating Option } \\
\text { Sigauke, Swansi, \& Tsvara }\end{array}$} \\
\hline & Glaser & Strauss & Charmaz & \\
\hline $\begin{array}{l}\text { Philosophical } \\
\text { underpinnings }\end{array}$ & $\begin{array}{l}\text { Soft positivism/Objectivist: } \\
\text { - Reality of an external world; } \\
\text { - Neutral observer; } \\
\text { - } \quad \text { fodes, categories and theory emerge } \\
\text { - What emerges }\end{array}$ & $\begin{array}{l}\text { Post positivism/Symbolic interactionism: } \\
\text { - Imperfect view of the world; } \\
\text { - Imperfect observer; } \\
\text { - Data imperfectly created through } \\
\text { interaction with the viewed world; } \\
\text { Codes, categories and theory are } \\
\text { imperfectly created through } \\
\text { interaction with the viewed world \& } \\
\text { created data } \\
\text { What we create }\end{array}$ & $\begin{array}{l}\text { Constructivist/ Symbolic interactionism: } \\
\text { - Viewed world; } \\
\text { - } \quad \text { Subjective observer; } \\
\text { Data constructed through interaction } \\
\text { - } \quad \text { codes the vatewed world; } \\
\text { constructed through interaction with } \\
\text { the viewed world \& created data } \\
\text { What we construct }\end{array}$ & $\begin{array}{l}\text { Pragmatism/Symbolic interactionism } \\
\text { - Interacted world } \\
\text { - Logical, scientific, practical } \\
\text { inquirer } \\
\text { What we do affects the data and } \\
\text { its outcomes } \\
\text { Codes, categories and theory are } \\
\text { constructed through the methods } \\
\text { we choose and our interaction } \\
\text { with the world } \\
\text { - What works }\end{array}$ \\
\hline Use of literature & Discouraged & $\begin{array}{l}\text { Use literature throughout the research } \\
\text { process }\end{array}$ & $\begin{array}{l}\text { Use literature throughout the research } \\
\text { process }\end{array}$ & $\begin{array}{l}\text { Use of literature depends on the } \\
\text { philosophical underpinning }\end{array}$ \\
\hline Coding & Open, selective, theoretical & Open, axial, selective, conditional matrix & Open, refocused & $\begin{array}{l}\text { A combination that works among the } \\
\text { different coding options \& cycles }\end{array}$ \\
\hline Theory & Emerges/discovered & Created & Constructed & Emergent, created, or constructed \\
\hline Uniting principles & & $\begin{array}{ll}- & \text { Constant compariso } \\
- & \text { Theoretical samplin } \\
- & \text { Memoing } \\
\text { - } & \text { Substantive vs form }\end{array}$ & theory & \\
\hline
\end{tabular}




\section{References}

Birks, M., \& Mills, J. (2011). Grounded Theory A practical Guide. Los Angels: SAGE.

Brayant, A., Charmaz, K., Covan, E. K., Star, S. L., Glaser, B. G., Stern, P. N., ... Jorg, S. (2010). The SAGE Handbook of Grounded Theory (Paperback; A. Bryant \& K. Charmaz, Eds.). London: SAGE.

Bryant, A. (2003). Qualitative Social A Constructive / ist Response to Glaser. Forum: Qualitative Social Research Sozialforschung, 4(1), 1-5.

Charmaz, K. (2014). Constructing Grounded Theory (2nd ed.; D. Silverman, Ed.). London: SAGE. Kindle Edition.

Corbin, J., \& Strauss, A. (2015). Basics of Qualitative Research Techniques and Procedures for Developing Grounded Theory (4th Editio). California: SAGE.

Fukofuka, S. (2012). Organisational Crisis: A Model of Emergence. (Unpublished doctoral dissertation). Adventist International Institute of Advanced Studies, Silang, Cavite, Philippines.

Glaser, B. G. (1998). Doing grounded theory: Issues and discussions. Mill Valley, CA: Sociology
Press.

Glaser, B. G., \& Holton, J. (2004). Remodeling Grounded Theory. FQS Forum: Qualitative Sozialforschung, 5(2), Art. 4. Retrieved from http://www.qualitative-

research.net/index.php/fqs/article/view/607

Glaser, B. G., \& Strauss, A. L. (1967). The Discovery of Grounded Theory: Strategies for Qualitative Research. In Observations (Vol. 1). https://doi.org/10.2307/2575405

Goulding, C. (1998). Grounded theory: the missing methodology on the interpretivist agenda. Qualitative Market Research: An International Journal, 1(1), 50-57. https://doi.org/10.1108/13522759810197587

Kenny, M., \& Fourie, R. (2015). The Qualitative Report Contrasting Classic, Straussian, and Constructivist Grounded Theory: Methodological and Philosophical Conflicts. The Qualitative Report, 20(8), 1270-1289. Retrieved from http://nsuworks.nova.edu/tqr\%5Cnhttp://nsu works.nova.edu/tqr/vol20/iss8/9

Tan, J. (2010). Grounded theory in practice: issues and discussion for new qualitative researchers. Journal of Documentation, 66(1), 93-112. https://doi.org/10.1108/00220411011016380 